\title{
Study of phases formed during sintering at different temperatures in ceramic composites containing gypsum waste
}

Pâmela Bento Cipriano ( $\sim$ pamela.ufcg@gmail.com )

Universidade Federal do Vale do São Francisco https://orcid.org/0000-0002-3013-3854

Tássila Galdino

Universidade Federal do Vale do Sao Francisco

Clebiano Sá

Universidade Federal do Vale do Sao Francisco

Andréa Ferraz

Universidade Federal do Vale do Sao Francisco

\section{Research Article}

Keywords: clay waste, ceramic bodies, gypsum waste, Araripina

Posted Date: April 7th, 2020

DOI: https://doi.org/10.21203/rs.3.rs-21149/v1

License: (a) (i) This work is licensed under a Creative Commons Attribution 4.0 International License.

Read Full License 


\section{Abstract}

Gypsum production generates wastes in the productive chain during the extraction of the clay cap on the gypsum and in the products manufacturing. The objective of this study was to make possible the reuse of two different types of wastes from the Polo Gesseiro of Araripe in red ceramics. 5 and $10 \%$ by mass of gypsum waste was incorporated into the clay waste. The specimens were molded through uniaxial pressing and then dried at $110^{\circ} \mathrm{C}$ for $24 \mathrm{~h}$, sintered at $850^{\circ} \mathrm{C}, 950^{\circ} \mathrm{C}$ and $1050^{\circ} \mathrm{C}$ for $2 \mathrm{~h}$. Linear shrinkage, water absorption, apparent porosity, loss on ignition and flexural strength were evaluated in the specimens. The results indicated that the best performance was obtained in sintered composites at 850 ${ }^{\circ} \mathrm{C}$. The formation of new phases in the sintered ceramic bodies was obtained by increasing the temperature and adding the gypsum waste. The presence of crystalline calcium phases indicates that reactions occurred between calcium sulfate and oxides of the material. The incorporation of gypsum waste into clay waste for the production of ceramic composites allowed the reduction of environmental impacts in the gypsum production chain.

\section{Introduction}

The possibility of using low-cost materials for the production of new ceramic products has been stimulated mainly aiming the industrial waste recycling. This initiative reinforces the importance of the utilization of waste as raw materials for the technological development of utility products for the society and environmental protection, since some waste can be polluting [1].

The use of industrial waste as additives in the manufacture of ceramic products has been widely studied in recent years. The addition of basaltic waste to ceramic bodies burned at $850^{\circ} \mathrm{C}$ contributed to the reduction of retraction in drying and burning [2]. Different wastes were incorporated in the ceramic mass: steel wastes from the production of steel in an electric furnace (powder for steelworks), wastes from a ceramic coating industry atomizer and from porcelain stoneware polishing. The ceramic masses were formed by pressing and subjected to burning at temperatures $800,900,1000$ and $1100^{\circ} \mathrm{C}$. The atomizer powder increased the sintering rate at temperatures below $950^{\circ} \mathrm{C}$ and at higher temperatures the powder for steelworks promoted a more intense sintering in the predominant region of solid-state sintering [3].

The incorporation of $10-50 \%$ of marble and granite sludge in sintered ceramic mass at temperatures between 950 and $1150^{\circ} \mathrm{C}$ was evaluated, enabling the use of the waste without negatively affecting the samples properties [4]. The production of tiles containing 5 to $20 \%$ of chamotte (burnt brick waste) allowed improvements in the drying stage [5].

A study of the sintering behavior at temperatures between 750 and $1150^{\circ} \mathrm{C}$ in ceramic materials was carried out with the addition of 5 to $20 \%$ of petroleum sludge waste in the clay masses. Significant phase transformations occurred during sintering. This waste presents a large amount of non-plastic materials (quartz and barite) that contribute to the reduction of linear shrinkage and mechanical resistance of the sintered bodies [6]. 
Currently there is a great concern on the part of the industries with the waste disposal generated throughout the production process, mainly in the mining area [7]. One of the main sources of environmental impact related to the gypsum extraction activities are the waste piles, which are arranged in the area consisting of fines derived from the dismantling and from sterile material removed in the mining operation [8]. The clay waste present in the material removed from the gypsum tillage is rich in clay minerals important for application in products of the red ceramic industry.

In the gypsum production, issues such as energy consumption and the high generation of gypsum waste during the productive cycle have a negative impact on the environment [9]. Currently, most research is focused on reducing the volume of waste by determining applications such as alternative material in the areas of civil and industrial Engineering [10].

The incorporation of $5 \%$ and $10 \%$ of gypsum wastes in clay was evaluated, considering two sintering temperatures $\left(800\right.$ and $1050^{\circ} \mathrm{C}$ ) for the production of red ceramic products, the best results were obtained with the addition of $5 \%$ of gypsum residue burned at $800{ }^{\circ} \mathrm{C}$ presenting properties similar to pure clay [11]. In the literature, the production of satisfactory formulations with red ceramic mass containing up to $15 \%$ of gypsum waste and illitic clay was reported at the burning temperatures of 850 and $950^{\circ} \mathrm{C}[12]$.

In this context, this study evaluated the possibility of incorporating gypsum waste into clay waste from the extraction of gypsum for the production of ceramic composites and to analyze the effect of the added waste content and sintering temperature on the physical, mechanical and morphological properties of the ceramic bodies, aiming to reuse waste materials as raw material and to reduce the amount of waste discarded in the environment.

\section{Experimental}

The wastes used were: a) waste clay - was obtained and denominate (B) by the gypsum mining company in the municipality of Araripina-PE and b) gypsum waste (WG) from the production of blocks and slabs in Juazeiro-BA.

The granulometric analysis was performed through laser diffraction in a granulometer of the brand Cilas, model 1064. The particle size was determined through wet method with material passed in sieve ABNT $\mathrm{N}^{\circ} 200(0.075 \mathrm{~mm})$.

The raw materials were passed in a sieve ABNT $N^{\circ} 80(0.180 \mathrm{~mm})$ and $\mathrm{N}^{\circ} 100(0.150 \mathrm{~mm})$, clay and gypsum waste, respectively. The ceramic mass was prepared with $8 \%$ water, 0,5 and $10 \%$ gypsum waste, then homogenized. The specimens were formed through uniaxial pressing (20 MPa) using a Bovenau brand hydraulic press $\left(60 \times 20 \times 5 \mathrm{~mm}^{3}\right)$. The specimens were oven dried at $110^{\circ} \mathrm{C}$ for 24 hours. The burning temperatures were $850^{\circ} \mathrm{C}, 950^{\circ} \mathrm{C}$ and $1050^{\circ} \mathrm{C}$, with a heating rate of $2^{\circ} \mathrm{C} \cdot \mathrm{min}^{-1}$, for $2 \mathrm{~h}$. The Table 1 presents the evaluated formulations. 


\section{Table 1. Ceramic bodies of formulation}

\begin{tabular}{lll} 
Samples & Clay (\%) & Gypsum waste (\%) \\
\hline B & 100 & 0 \\
\hline B/5\%WG & 95 & 5 \\
\hline B/10\%WG & 90 & 10
\end{tabular}

After the burning, the water absorption, the linear firing shrinkage, the loss on ignition, the apparent porosity and the flexural strength in three points were evaluated in the specimens, using a test speed of $0.5 \mathrm{~mm} \cdot \mathrm{min}^{-1}$, in universal mechanical testing equipment (EMIC-DL 1000).

Analysis of the crystalline phases of sintered specimens at $850^{\circ} \mathrm{C}$ and $1050^{\circ} \mathrm{C}$ was performed through $\mathrm{X}$-ray diffraction analysis in Shimadzu equipment, model XRD-6000. Using K-alpha copper radiation ( $\mathrm{I}=$ $0.15406 \mathrm{~mm}$ ), operating at $30 \mathrm{kV}$ and $30 \mathrm{~mA}$ at room temperature. The diffractograms were obtained from $2 \theta$ varying from 3 to $120^{\circ} \mathrm{C}$ and a scan speed of $2^{\circ} \cdot \mathrm{min}^{-1}$. The $X^{\prime}$ Pert HighScore Plus software version 2.0a and the PDF2 crystallographic chart standards were used for analysis of the X-ray diffraction patterns.

The morphological analysis of the fracture surface of the test specimens after the mechanical test was carried out using a Tescan brand electronic microscope, model Vega 3XMU, with energy dispersive spectroscopy (EDS) in an Oxford equipment (X-act) coupled to the scanning electron microscope. The contents of the elements present in the raw materials and in the sintered ceramic bodies were obtained. The samples were coated with gold for $10 \mathrm{~min}$ and $15 \mathrm{~mA} \cdot 5 \mathrm{~min}^{-1}$ current using a Quorum equipment (Q150R ES).

\section{Results And Discussion}

The Fig. 1 shows the distribution curves of the raw materials particle size. The "sand" fraction had the highest accumulated volume in the clay (62.57\%) and gypsum waste (87.05\%) (Table 2). In the clay particles larger than $20 \mu \mathrm{m}$ are associated with the presence of quartz [5]. The content of $87.8 \%$ of the "sand" fraction was obtained in the study of sand with coarser granulometry [13]. This content was similar to that found for gypsum waste.

The gypsum waste showed similar characteristics to the chamotte (burnt brick waste), because the waste had a coarser particle size than the clay, it may have contributed to a better packing of the particles [5].

The clay presents the granulometric distribution curve with a particle concentration between 0.8 and 32 $\mu \mathrm{m}$ while in the gypsum waste the particles were observed between 10 and $20 \mu \mathrm{m}$ (Fig. 1). 
Table 2. Raw materials granulometric Composition

\begin{tabular}{llll} 
Samples & Clay fraction $(<2 \mu \mathrm{m})$ & Silt fraction (between 2 and $20 \mu \mathrm{m})$ & Sand fracton $(\mathbb{2} 20 \mu \mathrm{m})$ \\
\hline B & 3,34 & 37,43 & 62,57 \\
WG & 0,74 & 12,95 & 87,05
\end{tabular}

The Table 3 presents the chemical analysis obtained through energy dispersive spectroscopy (EDS) of the raw materials and the ceramic materials with 5 and $10 \%$ of gypsum waste sintered at $950{ }^{\circ} \mathrm{C}$. The elements corresponding to the main component of gypsum waste, calcium sulfate dihydrate $\left(\mathrm{CaSO}_{4} \cdot 2 \mathrm{H}_{2} \mathrm{O}\right)$ were observed [14].

In the clay, elements that presented the highest levels were silicon, aluminum and oxygen attributed to silica $\left(\mathrm{SiO}_{2}\right)$ and alumina $\left(\mathrm{Al}_{2} \mathrm{O}_{3}\right)$ constituents of the clay materials, from the tetrahedral and octahedral layer of smectite clay minerals, kaolinites and accessory minerals [15]. The elements Fe, Mg and others may be due to isomorphic substitutions of the octahedral layer of smectite. Iron present in iron oxides plays an important role as flux during sintering [4]. The calcium content in the clay probably comes from the accessory mineral calcite [16].

In the sintered composites the presence of calcium and sulfur is due to the addition of gypsum waste, which at temperatures above $800{ }^{\circ} \mathrm{C}$ is formed the anhydrite $\left(\mathrm{CaSO}_{4}\right)$ as shown in Fig. 2.

\section{Table 3. Semiquantitative result of the present elements analyzed through EDS}

\begin{tabular}{|c|c|c|c|c|c|c|c|c|c|c|c|c|}
\hline \multirow[t]{2}{*}{ Sample } & \multicolumn{12}{|c|}{ Contents of present elements (\% in mass) } \\
\hline & 0 & Si & $\mathrm{Al}$ & $\mathrm{Fe}$ & K & $\mathrm{Mg}$ & $\mathrm{Ti}$ & $\mathrm{Ca}$ & $\mathrm{TI}$ & As & $S$ & $\mathrm{Mn}$ \\
\hline B & 54,9 & 20,4 & 8,5 & 4,8 & 1,0 & 0,6 & 0,4 & 1,4 & 0,6 & 0,3 & & \\
\hline WG & 64,2 & & & & & & & 20,4 & & & 15,4 & \\
\hline $\mathrm{B} / 5 \% W G$ & 54,1 & 22,9 & 8,1 & 4,3 & 0,9 & 0,7 & 0,3 & 5,3 & & & 3,3 & 0,1 \\
\hline$B / 10 \% W G$ & 48,5 & 27,7 & 8,5 & 8,0 & 0,7 & 0,7 & 0,3 & 3,9 & & & 1,6 & \\
\hline
\end{tabular}

The diffractograms of samples sintered at 850 and $1050^{\circ} \mathrm{C}$ are shown in Fig. 2. Significant phase transformations occurred during sintering as a function of the firing temperature, and in the composites the presence of gypsum waste influenced the formation of new phases.

It was observed in all the samples independent of the burning temperature studied, an intense quartz peak that may be related to the presence of rough quartz with dimensions greater than $45 \mu \mathrm{m}$ [17]. 
For the pure clay burned at $850^{\circ} \mathrm{C}$, only the presence of quartz is observed [18]. When increasing the temperature to $1050^{\circ} \mathrm{C}$ the presence of the crystalline phases of quartz, cristobalite, anorthoclase and hematite was verified. New phases were formed with increasing temperature due to a structural reorganization that occurs due to thermal decomposition, resulting in reduced porosity (Table 4) [17]. The cristobalite phase is formed at a sintering temperature between $1000^{\circ} \mathrm{C}$ and $1100^{\circ} \mathrm{C}$ due to the silica and alumina present in the clay [19]. The anorthoclase corresponds to an alkaline feldspar formed in high temperature [20]. The presence of hematite is associated with water loss from iron hydroxides [21].

The main phases of gypsum $\left(\mathrm{CaSO}_{4} \cdot 2 \mathrm{H}_{2} \mathrm{O}\right)$ are basanite $\left(\mathrm{CaSO}_{4} \cdot \frac{1}{2} \mathrm{H}_{2} \mathrm{O}\right)$ and anhydrite $\left(\mathrm{CaSO}_{4}\right)$, these transformations occur gradually with increasing temperature [22]. The presence of these phases is determined by reversible or irreversible dehydration reactions presenting different characteristics [23].

The crystalline phases observed with the incorporation of $5 \%$ gypsum waste at $850^{\circ} \mathrm{C}$ were quartz and anhydrite, while at $1050^{\circ} \mathrm{C}$ anorthite, cristobalite and hematite were also formed. The identified anhydrite has an orthorhombic crystal structure.

Phase transformations of $10 \%$ gypsum waste samples submitted to $850^{\circ} \mathrm{C}$ were characterized by quartz and anhydrite peaks. For the temperature of $1050^{\circ} \mathrm{C}$ were observed the phases: anhydrite, quartz, anorthite, hematite.

New phases such as the anorthite were formed in the compositions with gypsum sintered at a temperature of $1050^{\circ} \mathrm{C}$. The anorthite corresponds to a calcium crystalline phase probably resulting from the decomposition of calcium sulphate (gypsum waste) which reacted with the oxides present in the material. This behavior is expected in materials with high concentration of calcium oxide [4]. A similar result was reported in the literature on ceramic bodies containing $\mathrm{CaCO}_{3}$ sintered at $1050{ }^{\circ} \mathrm{C}$, which were formed among other phases the anorthite obtained by the calcium oxide reaction from the decomposition of calcium carbonate, with the metakaolin resulting from decomposition of kaolinite and quartz. The presence of anorthite indicates that the calcium oxide did not remain free but reacted with the metakaolin amorphous phase and forming a crystalline calcium phase [24].

A study reported in the literature showed that the gypsum waste presented different phase transformations as a function of temperature. The conversion of gypsum to anhydrite is independent of the heating rate and appears to be only thermodynamically controlled. Because this transformation involves only structural rearrangements that are not affected by the drying conditions [25].

The Fig. 3 shows the linear shrinkage of the samples studied. In the pure clay ceramic bodies, the shrinkage increased with risen temperature due to the densification occurred, decreasing the porosity as shown in Table 4.

In all compositions, shrinkage increased similarly at temperatures of 850 and $950^{\circ} \mathrm{C}$. The addition of gypsum reduced the shrinkage at $1050^{\circ} \mathrm{C}$ when compared to pure clay, showing a similar behavior independent of gypsum content. This behavior can be attributed to greater loss on ignition with the 
addition of gypsum. The reduction of linear shrinkage and mechanical resistance was reported in the literature in a ceramic material containing a waste composed mainly of quartz and barite, also significant phase transformations occurred during sintering [6].

\section{Table 3. Semiquantitative result of the present elements analyzed through EDS}

Sample Contents of present elements (\% in mass)

\begin{tabular}{lllllllllllll} 
& O & Si & Al & Fe & K & Mg & Ti & Ca & Tl & As & S & Mn \\
\hline B & 54,9 & 20,4 & 8,5 & 4,8 & 1,0 & 0,6 & 0,4 & 1,4 & 0,6 & 0,3 & & \\
\hline WG & 64,2 & & & & & & & 20,4 & & & 15,4 & \\
\hline B/5\%WG & 54,1 & 22,9 & 8,1 & 4,3 & 0,9 & 0,7 & 0,3 & 5,3 & & 3,3 & 0,1 \\
\hline B/10\%WG & 48,5 & 27,7 & 8,5 & 8,0 & 0,7 & 0,7 & 0,3 & 3,9 & & & 1,6 &
\end{tabular}

The diffractograms of samples sintered at 850 and $1050^{\circ} \mathrm{C}$ are shown in Fig. 2. Significant phase transformations occurred during sintering as a function of the firing temperature, and in the composites the presence of gypsum waste influenced the formation of new phases.

The loss on ignition and the apparent porosity were evaluated (Table 4). The loss on ignition was lower for the pure clay when compared to the composites. As the waste content increased, loss on ignition increased by $1050^{\circ} \mathrm{C}$. The overall porosity was not significantly altered at a temperature of $850^{\circ} \mathrm{C}$ in all compositions studied. The incorporation of gypsum increased the porosity with the increase of the burning temperature $\left(950\right.$ and $\left.1050^{\circ} \mathrm{C}\right)$ in relation to the pure clay.

\section{Table 4. Loss on ignition and apparent porosity of sintered specimens}

\begin{tabular}{|c|c|c|c|c|c|c|}
\hline \multirow[t]{2}{*}{ Samples } & \multicolumn{3}{|c|}{ Loss ignition (\%) } & \multicolumn{3}{|c|}{ Apparent porosity (\%) } \\
\hline & $850^{\circ} \mathrm{C}$ & $950^{\circ} \mathrm{C}$ & $1050^{\circ} \mathrm{C}$ & $850^{\circ} \mathrm{C}$ & $950^{\circ} \mathrm{C}$ & $1050^{\circ} \mathrm{C}$ \\
\hline B & $\begin{array}{l}12,27 \pm \\
0,11\end{array}$ & $\begin{array}{l}14,36 \pm \\
0,09\end{array}$ & $\begin{array}{l}12,97 \pm \\
0,06\end{array}$ & $\begin{array}{l}22,69 \pm \\
0,39\end{array}$ & $\begin{array}{l}15,45 \pm \\
0,59\end{array}$ & $\begin{array}{l}16,94 \pm \\
3,85\end{array}$ \\
\hline $\mathrm{B} / 5 \% W G$ & $\begin{array}{l}13,00 \pm \\
0,15\end{array}$ & $\begin{array}{l}14,23 \pm \\
0,14\end{array}$ & $\begin{array}{l}15,90 \pm \\
0,33\end{array}$ & $\begin{array}{l}22,29 \pm \\
0,74\end{array}$ & $\begin{array}{l}19,02 \pm \\
0,45\end{array}$ & $\begin{array}{l}18,79 \pm \\
0,73\end{array}$ \\
\hline $\mathrm{B} / 10 \% W G$ & $\begin{array}{l}13,67 \pm \\
0,41\end{array}$ & $\begin{array}{l}15,54 \pm \\
0,05\end{array}$ & $\begin{array}{l}18,59 \pm \\
0,04\end{array}$ & $\begin{array}{l}23,83 \pm \\
1,17\end{array}$ & $\begin{array}{l}20,02 \pm \\
0,45\end{array}$ & $\begin{array}{l}22,71 \pm \\
1,01\end{array}$ \\
\hline
\end{tabular}

Water absorption and flexural strength were evaluated (Fig. 4). The studied ceramic materials presented different water absorption rates for pure clay and $5 \%$ of gypsum residue burned at 950 and $1050{ }^{\circ} \mathrm{C}$, 
water absorption was between 6 and $10 \%$. While the compositions of clay and $5 \%$ of gypsum at $850{ }^{\circ} \mathrm{C}$ and $10 \%$ of gypsum at all temperatures had water absorption between 10 and $20 \%$. Therefore, all samples meet the maximum 20\% absorption limit for tile production according to NBR 15310 [26].

The pure clay showed the highest flexural strength when sintered at $950^{\circ} \mathrm{C}$. Throughout the sintering temperature range, mechanical strength showed a downward trend with increasing gypsum waste content. This behavior may be related to the microstructure of the sintered body and to the incorporation of the gypsum waste. The particles of the waste may be favoring the formation of defects such as cracks, reducing the mechanical strength of the sintered body.

The Fig. 5 presents the fracture surface of the pure clay ceramic bodies and the sintered composites at different temperatures. The differences observed in the microstructures are attributed to the presence of gypsum residue and the firing temperature [27]. The increase in the firing temperature gave rise to new phases that may influence the microstructure (Fig. 2).

The pure clay presented efficient sintering at all temperatures studied. In the composites a less, effective sintering was observed with the presence of some pores. In the ceramic bodies sintered at $1050^{\circ} \mathrm{C}$, the pores may be associated with the possible release of $\mathrm{O}_{2}$ from the reduction of hematite [21].

Probably, particle agglomerates in pure clay with $5 \%$ gypsum sintered at $1050{ }^{\circ} \mathrm{C}$ are cristobalite [28].

As shown in X-ray diffraction the anorthite peak arose with increasing sintering temperature. In microscopies of composites with 5 and $10 \%$ of gypsum burned at $1050^{\circ} \mathrm{C}$ can be observed grains, possibly anorthite. These results are like those found in the literature [29].

The Fig. 6 shows the EDS mapping of pure clay samples with $10 \%$ sintered gypsum waste at $950^{\circ} \mathrm{C}$. In the Fig. 6-a shows a good dispersion of the major clay elements. The Fig. 6-b presented small regions with a higher concentration of calcium and sulfur as expected due to the presence of the gypsum waste, and the other elements are characteristic of the clay. These regions may represent gypsum agglomerates in the ceramic matrix and act as stress concentrators and reduce mechanical properties.

\section{Conclusions}

The sustainable development requires greater production with the least amount of natural resources. The incorporation of gypsum waste into waste clay to produce ceramic composites allowed the use of waste materials minimizing the environmental impacts in the gypsum production chain. The formation of new phases in the sintered ceramic bodies was obtained by increasing the temperature and adding the gypsum waste. The presence of crystalline calcium phases indicates that reactions occurred between calcium sulphate and oxides of the material. Better mechanical properties of the composites were obtained at the firing temperature of $850^{\circ} \mathrm{C}$.

\section{Declarations}




\section{Acknowledgments}

The grant of the postdoctoral fellowship (PNPD/CAPES).

\section{References}

[1] Casagrande MC, Sartor MN, Gomes V, et al. Reaproveitamento de Resíduos Sólidos Industriais: Processamento e Aplicações no Setor Cerâmico. Cerâmica Industria/2008, 13:34-42.

[2] Mendes TM, Morales G, Reis PJ. Use of basaltic waste as red ceramic raw material. Cerâmica 2016, 62:157-162.

[3] Pureza JCC, Vicenzi J, Bergmann CP. Utilização de Resíduos de Baixa Granulometria como Matériaprima na Produção de Cerâmica Vermelha: Considerações quanto aos Mecanismos de Sinterização. Cerâmica Industrial 2007, 12: 27-33.

[4] Silva JB, Hotza D, Segadães AM, et al. Incorporação de lama de mármore e granito em massas argilosas. Cerâmica 2005, 51: 325-330.

[5] Vieira CMF, Souza ETA, Monteiro SN. Efeito da incorporação de chamote no processamento e microestrutura de cerâmica vermelha. Cerâmica 2004, 50: 254-260.

[6] Souza GP, Holanda JNF. Comportamento de sinterização de massas argilosas contendo resíduo proveniente do setor petrolífero. Cerâmica 2003, 49: 128-132.

[7] Penna CG. Efeitos da mineração no meio ambiente, Eco-Jornalismo Ambiental. Information on http://www.oeco.org.br/carlos-gabaglia-penna/20837-efeitos-da-mineracao-no-meio-ambiente, 2009.

[8] Melo KKS, Lima APC, Santana MC, et al. Caracterização química e mineralógica dos resíduos da mineração de gipsita no semiárido pernambucano. Holos 2017, 2: 214.

[9] Geraldo RH, Pinheiro SMM, Silva JS, et al. Gypsum plaster waste recycling: A potential environmental and industrial solution. Journal of Cleaner Production 2017, 164: 288-300.

[10] Ahmed A, Ugai K, Kamei T. Investigation of recycled gypsum in conjunction with waste plastic trays for ground improvement. Construction and Building Materials 2011, 25: 208-217.

[11] Cipriano PB, Rezende RTO, Ferraz AV. Produção de cerâmica vermelha utilizando argila da mineração de gipsita e resíduo de gesso. Acta Brasiliensis 2019, 3: 25-29.

[12] Silva JB. Avaliação da Potencialidade dos Resíduos de Gesso de Revestimento Incorporados em Formulações de massas cerâmicas. Thesis. Natal, Rio Grande do Norte: Universidade Federal do Rio Grande do Norte, 2008. 
[13] Queiroz LFT, Monteiro SN, Vieira CMF. Efeito da utilização de areia no processamento e nas propriedades de cerâmica vermelha. Cerâmica 2010, 56: 279-284.

[14] Ngernchuklin P, Yongpraderm N, Boonruang A, et al. Upgrading of waste gypsum for building materials. Key Engineering Materials 2016, 766: 211-216.

[15] Santos PS. Ciência e Tecnologia de Argilas. São Paulo, SP: Edgard Blücher, 1992.

[16] Pereira IDS, Silva IA, Cartaxo JM, et al. Estudos de caracterização dos novos depósitos de argilas esmectíticas do município de Sossego, PB. Cerâmica 2014, 60: 223-230.

[17] Santos RC, Silva TR, Neves GA, et al. Interação entre características de argilas e parâmetros de processamento sobre propriedades tecnológicas de corpos cerâmicos. Cerâmica 2017, 63: 361-368.

[18] Brito IP, Almeida EP, Neves GA, et al. Avaliação de novos depósitos de argilas do Estado da Paraíba visando sua aplicação como matérias-primas cerâmicas. Cerâmica 2015, 61:391-398.

[19] Kool A, Thakur P, Bagchi B, et al. Mechanical, dielectric and photoluminescence properties of alumina - mullite composite derived from natural Ganges clay. Applied Clay Science 2015,114: 349-358.

[20] Lira HL, Neves GA. Feldspatos: conceitos, estrutura cristalina, propriedades físicas, origem e ocorrências, aplicações, reservas e produção. Revista Eletrônica de Materiais e Processos 2013, 3: 110117.

[21] Andrade PM, Neto HSN, Monteiro SN, et al. Efeito da adição de fonolito na sinterização de argila caulinítica. Cerâmica 2005, 51:361-370.

[22] Liu C, Zheng H, Wang D. The dehydration kinetics of gypsum at high pressure and high temperature. High Pressure Research 2015, 35: 273-281.

[23] Comodi P, Kurnosov A, Nazzareni S, et al. The dehydration process of gypsum under high pressure. Physics and Chemistry of Minerals 2012, 39: 65-71.

[24] Lira C, Alarcon OE, Silveira MDM, et al. Efeitos da Composiçao e da Temperatura de Queima na Expansão por Umidade de Corpos Cerâmicos. Cerâmica Industrial 1997, 2: 27-30.

[25] Jacques SDM, Gonzalez-saborido A, Leynaud O, et al. Structural evolution during the dehydration of gypsum materials. Mineralogical Magazine 2009, 73: 421-432.

[26] ABNT NBR 15310 - Componentes cerâmicos - Telhas - Terminologia, requisitos e métodos de ensaio, 2005.

[27] Romano RCO, Pandolfelli VC. Obtenção e propriedades de cerâmicas porosas pela técnica de incorporação de espuma. Cerâmica 2006, 52: 213-219. 
[28] Motisuke M, Bertran CA. Síntese de "whiskers" de $\mathrm{CaSiO}_{3}$ em fluxo salino para elaboração de biomateriais. Cerâmica 2012, 58: 504-508.

[29] Zaiou S, Harabi A, Harabi E, et al. Sintering of anorthite based ceramics prepared from kaolin DD2 and calcite. Cerâmica 2016, 62: 317-322.

\section{Figures}
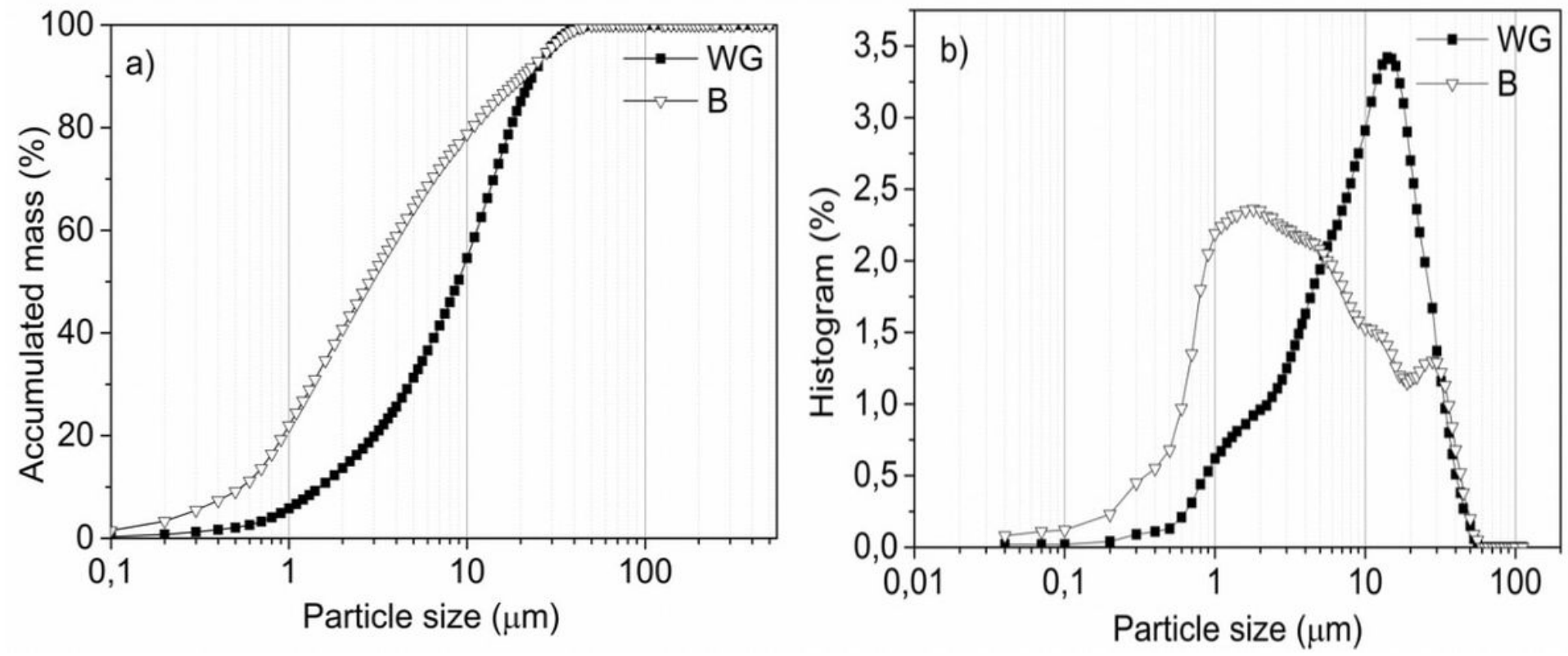

Figure 1

a) Granulometric distribution and b) Histogram of granulometric distribution of raw materials

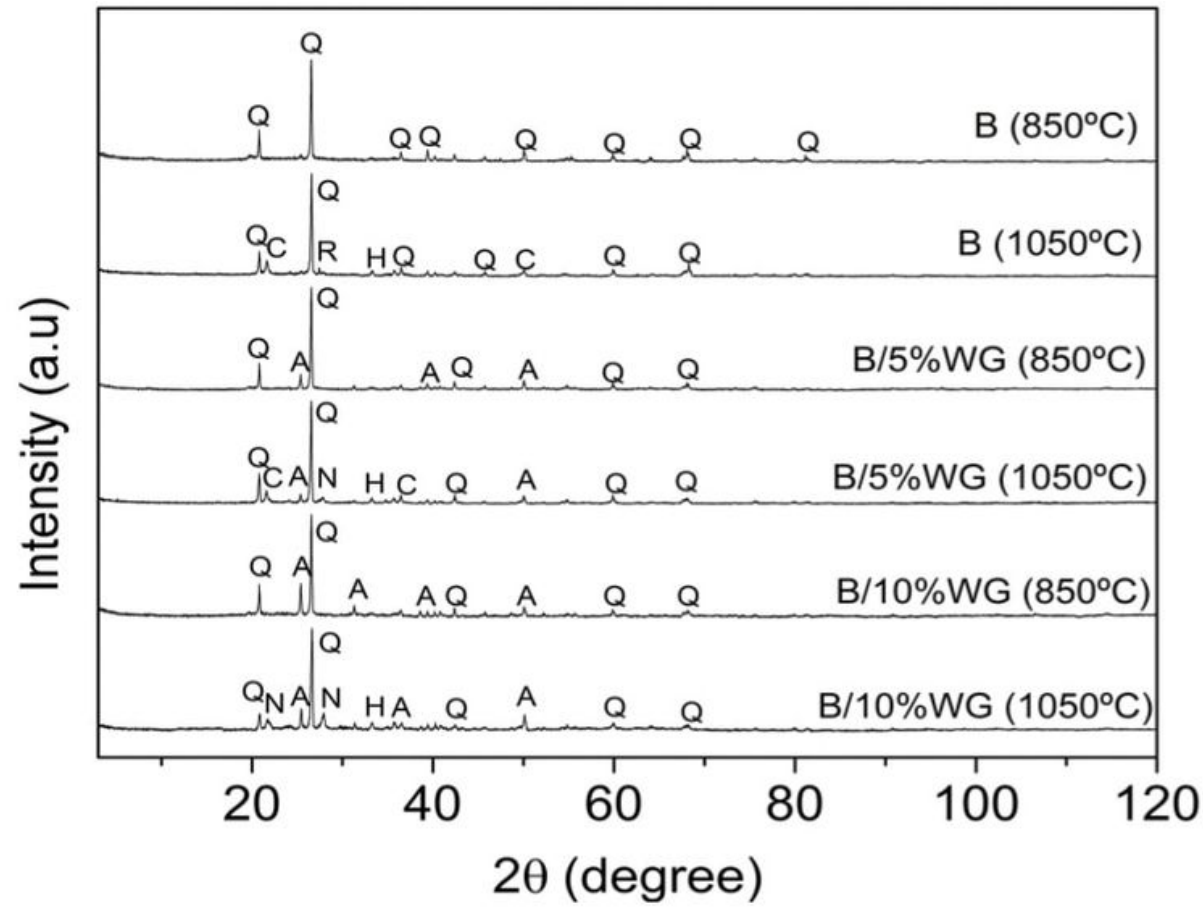

Quartz (Q) - ICSD $79634\left(\mathrm{SiO}_{2}\right)$

Cristobalite (C) - ICSD 34931 $\left(\mathrm{SiO}_{2}\right)$

Anorthoclase (R) - ICSD 3118

$\left(\mathrm{AlK}_{0.333} \mathrm{Na}_{0.667} \mathrm{O}_{8} \mathrm{Si}_{3}\right)$

Haematite (H) - ICSD $33643\left(\mathrm{Fe}_{2} \mathrm{O}_{3}\right)$

Anhydrite (A) - ICSD $16382\left(\mathrm{CaSO}_{4}\right)$

Anorthite (N) - ICSD 29361

$\left(\mathrm{CaA}{ }_{2} \mathrm{O}_{8} \mathrm{Si}_{2}\right)$ 
Figure 3

XRD patterns of samples sintered at different temperatures of pure clay and with 5 and $10 \%$ gypsum waste.

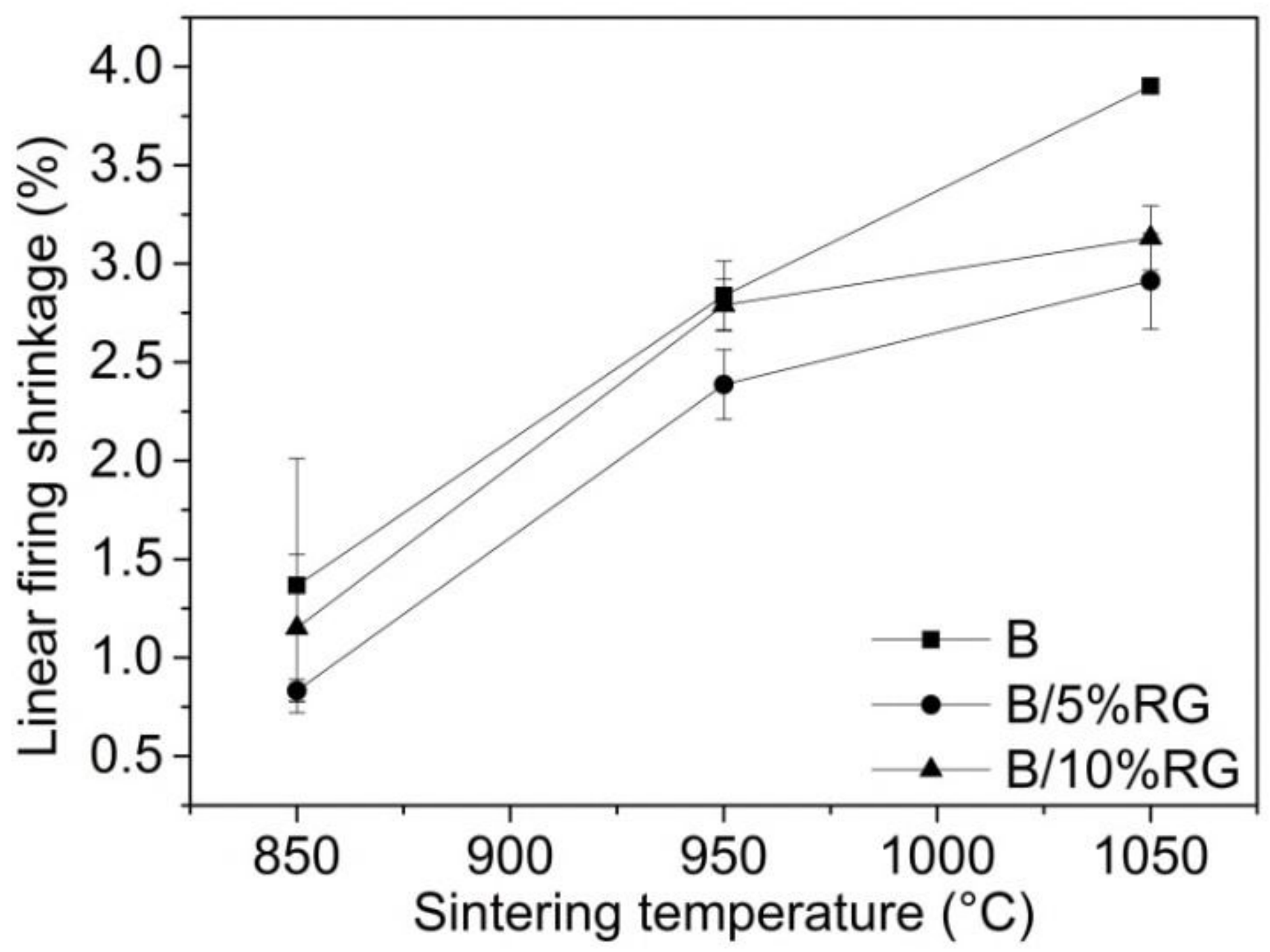

Figure 5

Linear firing shrinkage as a function of the sintering temperature of the ceramic specimens. 

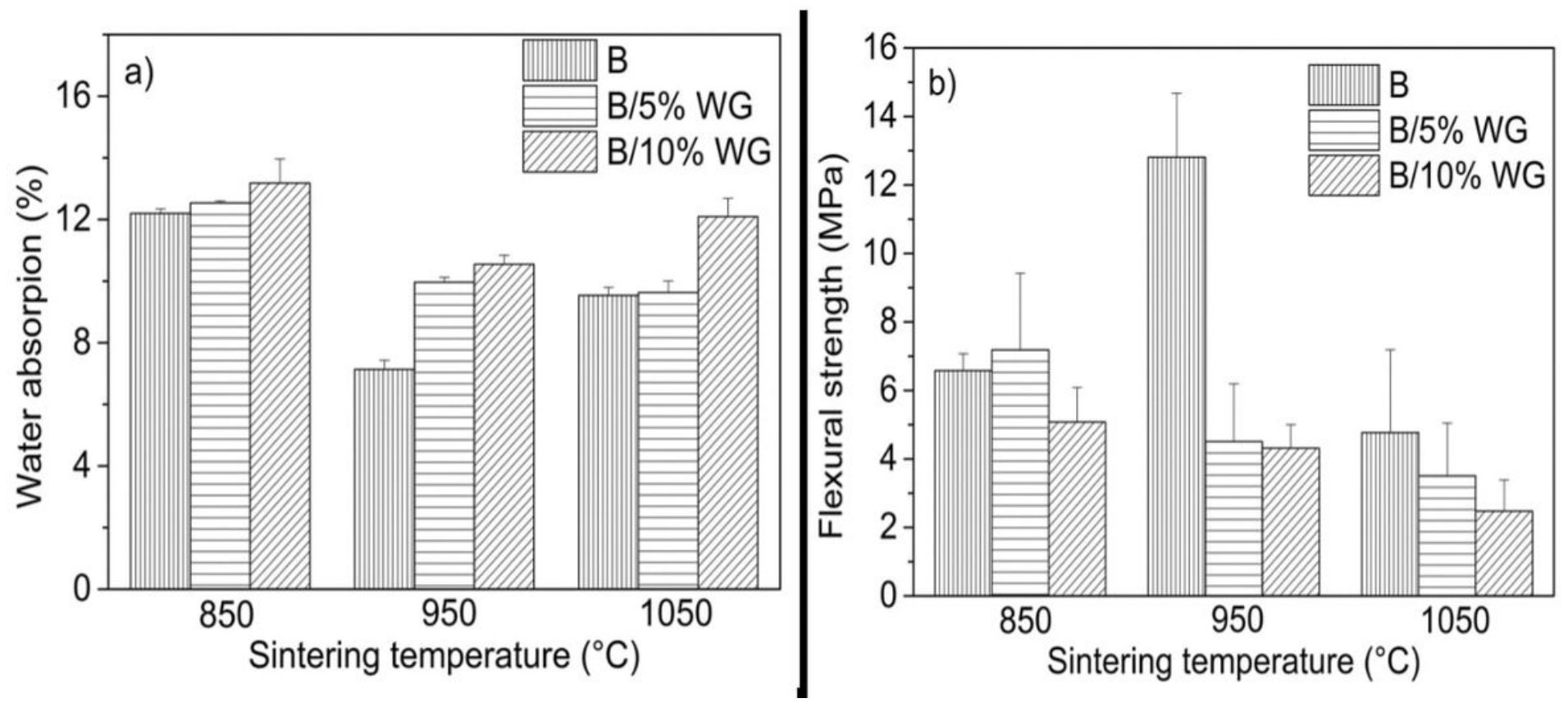

Figure 7

Water absorption and flexural strength for samples burned with different levels of gypsum waste. 

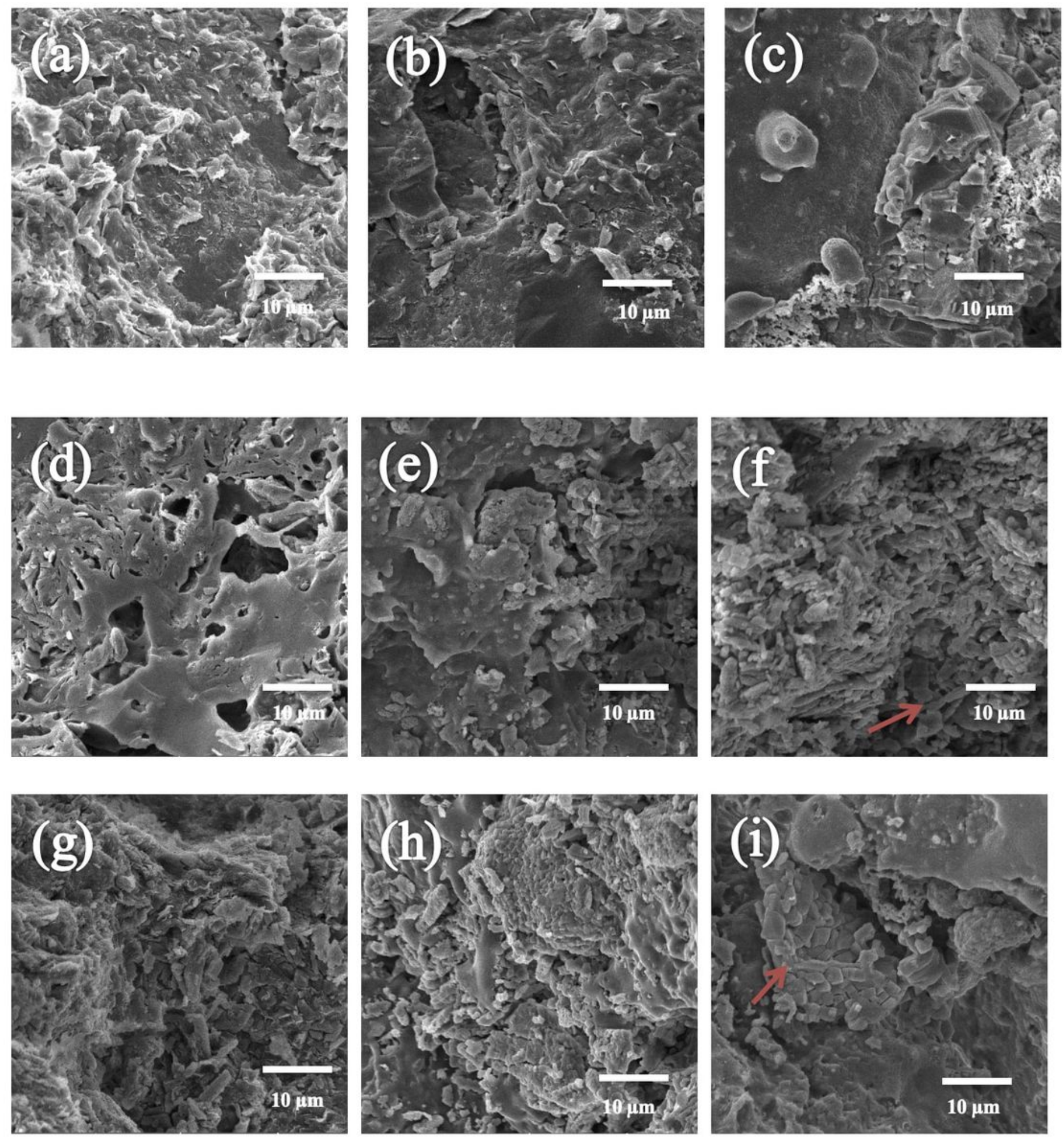

\section{Figure 9}

Micrographs of the fracture surface for the compositions sintered at $850^{\circ} \mathrm{C}$ : a) $\mathrm{B}$, d) $B / 5 \% W G$ e g) B/10\%WG; a $950^{\circ} \mathrm{C}$ : b) B, e) B/5\%WG e h) B/10\%WG; a $1050^{\circ} \mathrm{C}$ : c) B, f) $B / 5 \% W G$ e i) $B / 10 \% W G$. 


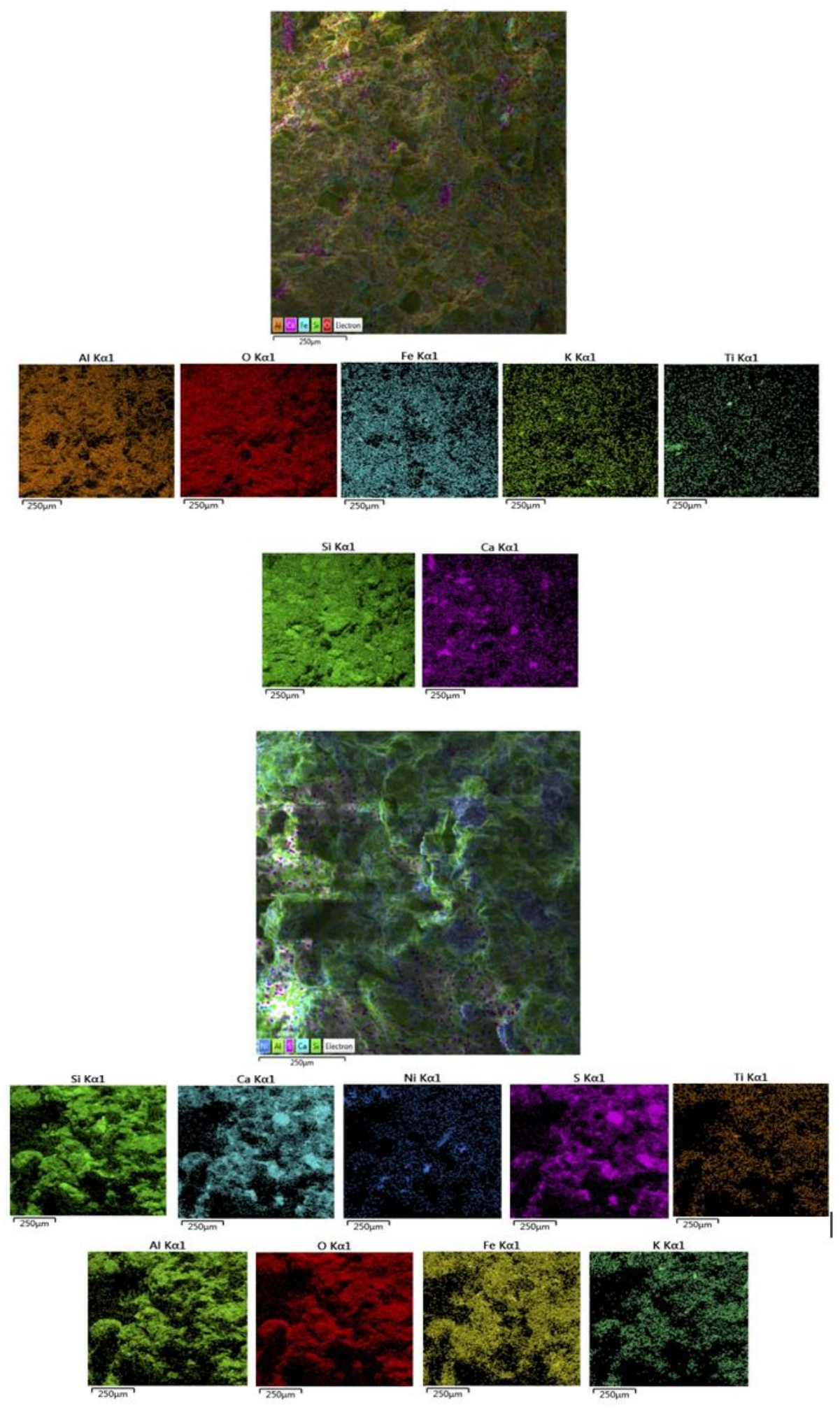

Figure 11

EDS mapping of the fracture surface of samples burned at $950^{\circ} \mathrm{C}:$ a) $\left.\mathrm{B} ; \mathrm{b}\right) \mathrm{B} / 10 \%$ WG. 